\title{
E3 ubiquitin ligase components (version 2019.5) in the IUPHAR/BPS Guide to Pharmacology Database
}

\author{
Elena Faccenda ${ }^{1}$ and Robert Layfield ${ }^{2}$ \\ 1. University of Edinburgh, UK \\ 2. The University of Nottingham, UK
}

\begin{abstract}
Ubiquitination (a.k.a. ubiquitylation) is a protein post-translational modification that typically requires the sequential action of three enzymes: E1 (ubiquitin-activating enzymes), E2 (ubiquitin-conjugating enzymes), and E3 (ubiquitin ligases) [16]. Ubiquitination of proteins can target them for proteasomal degradation, or modulate cellular processes including cell cycle progression, transcriptional regulation, DNA repair and signal transduction.

E3 ubiquitin ligases, of which there are $>600$ in humans, are a family of highly heterogeneous proteins and protein complexes that recruit ubiquitin-loaded E2 enzymes to mediate transfer of the ubiquitin molecule from the E2 to protein substrates. Target substrate specificity is determined by a substrate recognition subunit within the E3 complex.
\end{abstract}

\section{Contents}

This is a citation summary for E3 ubiquitin ligase components in the Guide to Pharmacology database (GtoPdb). It exists purely as an adjunct to the database to facilitate the recognition of citations to and from the database by citation analyzers. Readers will almost certainly want to visit the relevant sections of the database which are given here under database links.

GtoPdb is an expert-driven guide to pharmacological targets and the substances that act on them. GtoPdb is a reference work which is most usefully represented as an on-line database. As in any publication this work should be appropriately cited, and the papers it cites should also be recognized. This document provides a citation for the relevant parts of the database, and also provides a reference list for the research cited by those parts.

Please note that the database version for the citations given in GtoPdb are to the most recent preceding version in which the family or its subfamilies and targets were substantially changed. The links below are to the current version. If you need to consult the cited version, rather than the most recent version, please contact the GtoPdb curators.

\section{Database links}

E3 ubiquitin ligase components

http://www.guidetopharmacology.org/GRAC/FamilyDisplayForward?familyld=1023

Enzymes

cereblon

http://www.guidetopharmacology.org/GRAC/ObjectDisplayForward?objectld=3086

\section{References}

1. Asatsuma-Okumura T, Ito T and Handa H. (2019) Molecular mechanisms of cereblon-based drugs. 
Pharmacol. Ther. 202: 132-139 [PMID:31202702]

2. Chamberlain PP, Lopez-Girona A, Miller K, Carmel G, Pagarigan B, Chie-Leon B, Rychak E, Corral LG, Ren YJ and Wang M et al.. (2014) Structure of the human Cereblon-DDB1-lenalidomide complex reveals basis for responsiveness to thalidomide analogs. Nat. Struct. Mol. Biol.21: 803-9 [PMID:25108355]

3. Del Prete D, Rice RC, Rajadhyaksha AM and D'Adamio L. (2016) Amyloid Precursor Protein (APP) May Act as a Substrate and a Recognition Unit for CRL4CRBN and Stub1 E3 Ligases Facilitating Ubiquitination of Proteins Involved in Presynaptic Functions and Neurodegeneration. J. Biol. Chem. 291: 17209-27 [PMID:27325702]

4. Fischer ES, Böhm K, Lydeard JR, Yang H, Stadler MB, Cavadini S, Nagel J, Serluca F, Acker V and Lingaraju GM et al.. (2014) Structure of the DDB1-CRBN E3 ubiquitin ligase in complex with thalidomide. Nature 512: 49-53 [PMID:25043012]

5. Gandhi A, Dimartino J and Chopra R. (2014) Methods for the treatment of locally advanced breast cancer Patent number: WO2014039960A1.

6. Gandhi AK, Kang J, Havens CG, Conklin T, Ning Y, Wu L, Ito T, Ando H, Waldman MF and Thakurta ßet al.. (2014) Immunomodulatory agents lenalidomide and pomalidomide co-stimulate T cells by inducing degradation of $\mathrm{T}$ cell repressors Ikaros and Aiolos via modulation of the E3 ubiquitin ligase complex CRL4(CRBN.). Br. J. Haematol. 164: 811-21 [PMID:24328678]

7. Hagner PR, Man HW, Fontanillo C, Wang M, Couto S, Breider M, Bjorklund C, Havens CG, Lu G and Rychak E et al.. (2015) CC-122, a pleiotropic pathway modifier, mimics an interferon response and has antitumor activity in DLBCL. Blood 126: 779-89 [PMID:26002965]

8. Hartmann MD, Boichenko I, Coles M, Zanini F, Lupas AN and Hernandez Alvarez B. (2014) Thalidomide mimics uridine binding to an aromatic cage in cereblon. J. Struct. Biol. 188: 225-32 [PMID:25448889]

9. Heim C, Pliatsika D, Mousavizadeh F, Bär K, Hernandez Alvarez B, Giannis A and Hartmann MD. (2019) De-Novo Design of Cereblon (CRBN) Effectors Guided by Natural Hydrolysis Products of Thalidomide Derivatives. J. Med. Chem. 62: 6615-6629 [PMID:31251063]

10. Higgins JJ, Hao J, Kosofsky BE and Rajadhyaksha AM. (2008) Dysregulation of large-conductance Ca2+activated $\mathrm{K}+$ channel expression in nonsyndromal mental retardation due to a cereblon p.R419X mutation. Neurogenetics 9: 219-23 [PMID:18414909]

11. Higgins JJ, Pucilowska J, Lombardi RQ and Rooney JP. (2004) A mutation in a novel ATP-dependent Lon protease gene in a kindred with mild mental retardation. Neurology 63: 1927-31 [PMID:15557513]

12. Ito $T$, Ando H, Suzuki T, Ogura T, Hotta K, Imamura Y, Yamaguchi $Y$ and Handa H. (2010) Identification of a primary target of thalidomide teratogenicity. Science 327: 1345-50 [PMID:20223979]

13. Ito $\mathrm{T}$ and Handa H. (2016) Cereblon and its downstream substrates as molecular targets of immunomodulatory drugs. Int. J. Hematol. 104: 293-9 [PMID:27460676]

14. Lopez-Girona A, Mendy D, Ito T, Miller K, Gandhi AK, Kang J, Karasawa S, Carmel G, Jackson P and Abbasian $\mathrm{M}$ et al.. (2012) Cereblon is a direct protein target for immunomodulatory and antiproliferative activities of lenalidomide and pomalidomide. Leukemia 26: 2326-35 [PMID:22552008]

15. Matyskiela ME, Zhang W, Man HW, Muller G, Khambatta G, Baculi F, Hickman M, LeBrun L, Pagarigan B and Carmel G et al.. (2018) A Cereblon Modulator (CC-220) with Improved Degradation of Ikaros and Aiolos. J. Med. Chem. 61: 535-542 [PMID:28425720]

16. Morreale FE and Walden H. (2016) Types of Ubiquitin Ligases.Cell 165: 248-248.e1 [PMID:27015313]

17. Nguyen TV, Lee JE, Sweredoski MJ, Yang SJ, Jeon SJ, Harrison JS, Yim JH, Lee SG, Handa H and Kuhlman B et al.. (2016) Glutamine Triggers Acetylation-Dependent Degradation of Glutamine Synthetase via the Thalidomide Receptor Cereblon. Mol. Cell 61: 809-20 [PMID:26990986]

18. Sheereen A, Alaamery M, Bawazeer S, Al Yafee Y, Massadeh S and Eyaid W. (2017) A missense mutation in the CRBN gene that segregates with intellectual disability and self-mutilating behaviour in a consanguineous Saudi family. J. Med. Genet. 54: 236-240 [PMID:28143899] 